\title{
Az Észlelt Stressz Kérdőív járványspecifikus verziójának validálása
}

\author{
Hamvai Csaba dr. ${ }^{1}$ - Fáber Ágoston dr. ${ }^{2}$ - Konkolÿ Thege Barna dr. ${ }^{3,4}$ \\ ${ }^{1}$ Szegedi Tudományegyetem, Általános Orvostudományi Kar, Magatartástudományi Intézet, Szeged \\ ${ }^{2}$ Replika folyóirat, Budapest \\ ${ }^{3}$ Waypoint Research Institute, Waypoint Centre for Mental Health Care, Penetanguishene, Ontario, Canada \\ ${ }^{4}$ Department of Psychiatry, University of Toronto, Toronto, Ontario, Canada
}

Bevezetés: Egyre több adat bizonyítja, hogy a COVID-19-járvány hatással van a pszichés egészségre, beleértve a megnövekedett észlelt stresszt is.

Célkitüzés: Az Észlelt Stressz Kérdőív 10 tételes, járványspecifikus verziójának (PSS-PAN) megalkotása, validitásának és megbízhatóságának tesztelése.

Módszer: A skála faktorstruktúráját, konvergens és divergens validitását teszteltük egy internetes vizsgálat során (n = 1164; átlagéletkor: 38,57 év; szórás: 6,27 év; 84,2\% nő).

Eredmények: Igazoltuk a PSS-PAN egykomponensű szerkezetét. A kérdőív továbbá szignifikánsan korrelált a rövidített Beck Depresszió Kérdőív $(\mathrm{r}=0,41 ; \mathrm{n}=1164 ; \mathrm{p}<0,001)$, a 4 tételes Észlelt Stressz Kérdőív $(\mathrm{r}=0,46 ; \mathrm{n}=1164$; $\mathrm{p}<0,001)$ és az Élettel Való Elégedettség Skála pontszámaival $(\mathrm{r}=-0,29 ; \mathrm{n}=1164 ; \mathrm{p}<0,001)$. A nók esetében a PSS-PAN átlaga szignifikánsan magasabb volt, mint a férfiaknál $\left(\mathrm{t}_{(1162)}=-7,135 ; \mathrm{p}<0,001\right)$, de ez a hatásnagyság nagyon csekély volt (Cohen-féle $\mathrm{d}=0,06)$. A PSS-PAN átlagpontszáma szignifikánsan nem különbözött a legmagasabb iskolai végzettség kategóriái mentén $\left(\mathrm{F}_{(6 ; 1157)}=2,035 ; \mathrm{p}=0,06 ; \eta^{2}=0,01\right)$. Az alsó középosztályba tartozó résztvevők átlagpontszáma szignifikánsan magasabb volt, mint a középosztályba tartozó kitöltőké a post hoc elemzés alapján $\left(\mathrm{F}_{(4 ; 1159)}=3,461 ; \mathrm{p}=0,01 ; \eta^{2}=0,01\right)$. A skála pontszáma nem korrelált szignifikánsan az életkorral $(\mathrm{r}=-0,04$; $\mathrm{n}=1164 ; \mathrm{p}=0,13)$. A Cronbach-alfa 0,89 volt, vagyis a kérdőív belső megbízhatósága kiváló.

Megbeszélés: A skála egykomponensû struktúrát mutatott. A többi skálával való közepesen erôs és gyenge korrelációja a skála validitását igazolta, és azt, hogy a járványhoz kapcsolódó észlelt stressz külön indikátora. Pontszámát nem vagy nem erősen befolyásolta a nem, a kor, az iskolázottság vagy a szocioökonómiai státusz.

Következtetés: A PSS-PAN a járványokhoz kötődő stressz mérésének megfelelő eszköze. Orv Hetil. 2021; 162(35): 1391-1396.

Kulcsszavak: pszichológiai stressz, COVID-19, kérdőívfejlesztés, érvényesség, megbízhatóság

\section{Validation of pandemic-specific version of the Perceived Stress Scale}

Introduction: A growing amount of evidence indicates that the COVID-19 pandemic influences mental health, including an increased level of perceived stress.

Objective: To develop and psychometrically investigate a pandemic-specific version of the Perceived Stress Scale (PSS-PAN) that measures stress related to the pandemic.

Method: Factor structure as well as convergent and divergent validity of the 10 -item PSS-PAN were examined on the data set of an online survey ( $\mathrm{n}=1164$; mean age: 38.57 years; standard deviation: 6.27 years; $84.2 \%$ women).

Results: A one-factor structure for the PSS-PAN was confirmed. The scale correlated significantly with scores on the Shortened Beck Depression Inventory $(\mathrm{r}=0.41 ; \mathrm{n}=1164 ; \mathrm{p}<0.001)$, the 4-item Perceived Stress Scale $(\mathrm{r}=0.46 ; \mathrm{n}$ $=1164 ; \mathrm{p}<0.001)$, and the Satisfaction with Life Scale $(\mathrm{r}=-0.29 ; \mathrm{n}=1164 ; \mathrm{p}<0.001)$. Women's PSS-PAN scores were significantly higher than men's $\left(\mathrm{t}_{(1162)}=-7.135 ; \mathrm{p}<0.001\right)$ but this difference was trivial $($ Cohen's $\mathrm{d}=0.06)$. Further, scale scores did not differ significantly across educational attainment $\left(\mathrm{F}_{(6 ; 1157)}=2.035 ; \mathrm{p}=0.06 ; \eta^{2}=0.01\right)$. Lower middle class participants' mean scores were significantly higher than those of middle-class respondents according to the post hoc test $\left(\mathrm{F}_{(4 ; 1159)}=3.461 ; \mathrm{p}=0.01 ; \eta^{2}=0.01\right)$. PSS-PAN scores did not correlate significantly with age $(\mathrm{r}=-0.04 ; \mathrm{n}=1164 ; \mathrm{p}=0.13)$. Cronbach's alpha was 0.89 indicating excellent internal consistency. 
Discussion: The PSS-PAN has a single-component structure. Moderately strong and weak correlations with other scales support its convergent and divergent validity and indicate that it is a distinct indicator of pandemic-related perceived stress. Its total score was not or not strongly associated with gender, age, education level, or socioeconomic status. Conclusion: The PSS-PAN is a proper instrument to measure pandemic-specific perceived stress.

Keywords: psychological stress, COVID-19, scale development, reliability, validity

Hamvai Cs, Fáber Á, Konkolÿ Thege B. [Validation of pandemic-specific version of the Perceived Stress Scale]. Orv Hetil. 2021; 162(35): 1391-1396.

(Beérkezett: 2021. február 9.; elfogadva: 2021. március 3.)

\section{Rövidítések}

BDI $=($ Beck Depression Inventory $)$ Beck Depresszió Kérdőív; COVID-19 = (coronavirus disease 2019) koronavírus-betegség 2019; PSS = (Perceived Stress Scale $)$ Észlelt Stressz Kérdőív; PSS-PAN = (Perceived Stress Scale - Pandemic $)$ az Észlelt Stressz Kérdőív járványspecifikus verziója; SARS-CoV-2 = (severe acute respiratory syndrome coronavirus 2 ) súlyos akut légúti tünetegyüttest okozó koronavírus- $2 ;$ SWLS $=$ (Satisfaction with Life Scale) Élettel Való Elégedettség Skála

A COVID-19 egy új koronavírus, az úgynevezett SARSCoV-2 által okozott megbetegedés. A betegségrôl az Egészségügyi Világszervezet először 2019. december 31-én szerzett tudomást, miután a Kínai Népköztársaság Vuhan városában számos, vírusos tüdőgyulladással járó esetról számolt be [1]. A Johns Hopkins Egyetem 2021. január 27-én közzétett adatai alapján a rendkívül gyorsan terjedő vírus világszerte 100364285 esetért felelős, és a világon 2160402 fó halt meg a hozzá kapcsolódó betegségben. Magyarországon a COVID-19-hez köthetó esetek száma 361881 , és eddig 12198 fó hunyt el ebben a betegségben [2].

A járvány nemcsak élettani hatásokkal, de komoly negatív pszichológiai következményekkel is járhat. Ezek közé tartozik a COVID-19-hez kapcsolódó stresszhatás is. Egy 5 tanulmányt magában foglaló metaanalízis alapján az általános lakosság körében a COVID-19-járványhoz köthető, klinikailag jelentős stressz prevalenciája 29,6\%-ra tehető [3]. Orvosi szempontból lényeges, hogy az észlelt stressz szintje számos szomatikus és mentális tünettel járhat együtt. Kimutatták például, hogy az Észlelt Stressz Kérdőívvel (Perceived Stress Scale, PSS) mért észlelt stressz l pontnyi emelkedésével 10\%-kal megnőtt a gyulladásos arthritis megjelenési valószínúsége [4]. Más tanulmányok szerint az észlelt stressz közepes vagy magas szintje összességében rosszabb immunitással és magasabb oxidatív, illetve gyulladásos stresszel járt együtt [5]. További adatok szerint a migrénben szenvedő betegek észleltstressz-szintje szignifikánsan magasabb volt a kontrollcsoportéhoz képest [6]. Gastrointestinalis problémával küzdő betegek észleltstressz-szintje pedig depresszióval, alvászavarral, az átlagos fájdalomszinttel, a legrosszabb fájdalomszinttel, valamint alacso- nyabb életminőséggel járt együtt [7]. A fenti korrelációkból nem lehet teljes bizonyossággal az ok és okozat irányát meghatározni. Ennek ellenére kitúnik, hogy egyes tanulmányok azt implikálják, hogy az észlelt stressz befolyásolhatja bizonyos szomatikus tünetek kialakulását, és vica versa, a testi tünetek fokozhatják az észlelt stressz szintjét. Valószínú, hogy a testi tünetek és az észlelt stressz kölcsönös és cirkuláris egymásra hatása jelenik meg ezekben az eredményekben. Még nem állnak rendelkezésünkre olyan kutatási adatok, amelyek kifejezetten a COVID-járványhoz kötődő észlelt stressz és a specifikus testi tünetek közötti kapcsolatok feltárását célozzák, de feltételezésünk szerint a közeljövőben számítani lehet ilyen jellegú vizsgálatokra is. Jelenleg azok a kutatások dominálnak, amelyek a COVID-19-járványhoz kapcsolódó észlelt stressz mentális problémákkal való kapcsolatára fókuszálnak. Például a COVID-19-fertőzés miatt kórházban fekvő betegek esetében az észlelt stressz szignifikánsan korrelált a depresszióval és a szorongással [8]. Kínában pedig a járvány miatt izolálódott személyek észleltstressz-szintje és szorongása között mutattak ki szignifikáns kapcsolatot, amelyet a helyzet kognitív átértékelése módosított [9].

A fentiek miatt nem meglepő, hogy a pandémia alatt folyamatosan fejlesztenek ki olyan pszichológiai eszközöket, amelyek specifikusan a COVID-19 pszichés hatását (köztük a járványhoz köthető stresszt) hivatottak mérni [10]. Tudomásunk szerint jelenleg még nem érhető el olyan magyar nyelvű eszköz, amely a COVID19-járványhoz kapcsolódó pszichés hatást, még konkrétabban az észlelt stresszt mérné. Célunk egy ilyen eszköz kifejlesztése és validálása volt. Munkánk során PedrozoPupo és mtsai ötletére támaszkodtunk, akik saját tanulmányukban a PSS-t módosították úgy, hogy az speciálisan a járvánnyal kapcsolatos észlelt stresszt mérje [11]. Választásunkat indokolta, hogy a PSS [12] a szubjektív stressz mérésének széles körben elterjedt, bevált eszköze, magyar nyelven validált változata is elérhető [13], valamint a pandémiaspecifikus változat (a továbbiakban PSSPAN) elkészítése az eredeti eszköz minimális módosításával lehetséges volt.

A PSS-PAN konvergens validitását a depresszió és az általános észlelt stressz-szint segítségével vizsgáltuk. 
Hipotézisünk szerint a járványspecifikus észlelt stressz a depresszió és az általános észlelt stressz szintjével egyaránt szignifikánsan és pozitívan korrelál. A skála divergens validitását az élettel való elégedettség mérésével teszteltük. Hipotézisként fogalmaztuk meg, hogy a járványspecifikus észlelt stressz és az élettel való elégedettség szignifikánsan, negatívan korrelál egymással.

\section{Módszer}

\section{Résztvevők és eljárás}

A PSS-PAN validálása egy másik kutatás keretén belül zajlott, amellyel a szülői kiégést szerettük volna vizsgálni, és amelyre 2021 januárjában került sor. A vizsgálat etikai engedélyét az Egyesített Pszichológiai Kutatásetikai Bizottság adta ki 2021-02 referenciaszámon. Beválasztási kritérium volt a betöltött 18. életév és az, hogy a kitöltő legalább egy gyermekével egy háztartáson belül éljen. Az online tesztbattériát Google Forms (Google LLC, Mountain View, CA, Amerikai Egyesült Államok) segítségével készítettük el. A mintavételi eljárás során az úgynevezett hólabda (snowball) módszert alkalmaztuk: különböző Facebook-csoportokban osztottuk meg a kérdőív linkjét, és megkértük a kitöltőket, hogy a beválasztási kritériumnak megfelelő ismerőseikkel is osszák azt meg. Mind a kérdőívben, mind a közösségi médiában történő felhívásban tájékoztattuk a kitöltőket, hogy a vizsgálat anonim, a kitöltő azonosítását lehetővé tévő adatokat nem igényel, és bármikor indok nélkül megszakítható. A vizsgálatban 1164 fó vett részt; a kitöltők 84,2\%-a nő, az életkori átlag 38,57 év, az életkori szórás 6,27 év volt. A válaszadók közül legtöbben (29,7\%), főiskolát vagy egyetemet végeztek, és mindössze 0,9\%-uknak volt a legmagasabb iskolai végzettsége 8 általános iskolai osztály. A minta többsége $(61,72 \%)$ a középosztályba sorolta magát a szocioökonómiai helyzete alapján, és csupán $0,71 \%$ ítélte meg úgy, hogy a felső társadalmi osztályba tartozik.

\section{Eszközök}

A kérdőívcsomagban több kérdéscsoport is szerepelt; itt csak azokat ismertetjük, amelyek a jelen kutatás szempontjából relevánsak. A demográfiai változók között rákérdeztünk a kitöltők nemére, életkorára, legmagasabb iskolai végzettségére, szubjektív szocioökonómiai státuszára.

A PSS-PAN megalkotása során a PSS [12] magyar verziójának 10 tételes változatát vettük alapul [13]. PedrozoPupo, Pedrozo-Cortés, Campo-Arias eljárása nyomán [11] ezt a skálát a lehetô legminimálisabban módosítottuk úgy, hogy az instrukcióba, illetve az egyes tételekbe beillesztettük a „járvány” szót, valamint a 6 . tételbe a „fertőzés” kifejezést. Az így kapott eszközhöz az eredetivel azonos, ötfokú Likert-skálát alkalmaztunk, ahol 0 = „Soha”; 4 = „Nagyon gyakran”.
Az általános észleltstressz-szintet a PSS [12] magyar verziójának 4 tételes változatával mértük [13]. A teszt ötfokú Likert-skáláján $0=$ „Soha”; 4 = „Nagyon gyakran”. A jelen mintán a belső megbízhatóság kitűnőnek bizonyult (Cronbach-alfa $=0,83$ ).

A depresszió mérésére a Beck Depresszió Kérdőív (Beck Depression Inventory, BDI) rövidített, 9 tételes változatát alkalmaztuk. A válaszadók négyfokú Likertskálán adhatják meg válaszukat, ahol 1 = „Egyáltalán nem jellemző"; $4=$ „Teljesen jellemző” $[14,15]$. A jelen mintán a belső megbízhatóság kitűnőnek bizonyult (Cronbach-alfa $=0,84)$.

A szubjektív jóllétet az Élettel Való Elégedettség Skála (Satisfaction with Life Scale, SWLS) segítségével mértük fel. Az öttételes eszköz az élettel való elégedettség különböző aspektusait méri fel hétfokú Likert-skálán, ahol $1=$ „Egyáltalán nem értek egyet”; 7 = „Teljes mértékben egyetértek" $[16,17]$. A jelen mintán e skála belső megbízhatósága is kitűnőnek bizonyult (Cronbach-alfa = $0,88)$.

\section{Statisztikai elemzés}

A statisztikai elemzést az IBM SPSS Statistics 25-ös verziója (IBM Corporation, Armonk, NY, Amerikai Egyesült Államok) segítségével végeztük. Feltáró faktoranalízist alkalmazva fookomponens-elemzéssel vizsgáltuk a PSS-PAN faktorstruktúráját. Az úgynevezett párhuzamos elemzés (paralell analysis) módszerét használtuk arra, hogy meghatározzuk a komponensek számát. A módszer egy Monte -Carlo-szimuláció, amely egy random módon generált adathalmaz sajátértékeit (eigenvalue) a kutatási mintán nyert sajátértékekkel veti össze [18]. Egy komponenst akkor tartunk meg, ha sajátértéke meghaladja a random adathalmaz szimulált komponensének sajátértékét. A random sajátértékeket egy külön erre a módszerre megalkotott internetes alkalmazás segítségével nyertük [19]. A konvergens és divergens validitás megállapítására korrelációs elemzést futtattunk le a PSS-PAN, valamint a BDI, PSS, SWLS között. Független mintás t-próbával teszteltük a PSS-PAN esetleges nemi különbségeit. Egyszempontos varianciaanalízissel mértük a PSS-PAN-pontszám esetleges különbségét a legmagasabb iskolai végzettség, illetve a szocioökonómiai státusz egyes értékei mentén. Korrelációval vizsgáltuk az életkor és a PSS-PAN-pontszám kapcsolatát. Az eszköz belső konzisztenciáját Cronbach-alfa mutatóval vizsgáltuk.

\section{Eredmények}

\section{Faktoranalizis}

A Bartlett-teszt szignifikáns $\left(\chi^{2}=5257\right.$; $\left.p<0,001\right)$, a Kaiser-Meyer-Olkin-mutató 0,91 volt, amely kiváló. Ezek alapján a faktoranalízisbe bevont változók alkalmasak voltak a további elemzésre. A fookomponens-elemzés 


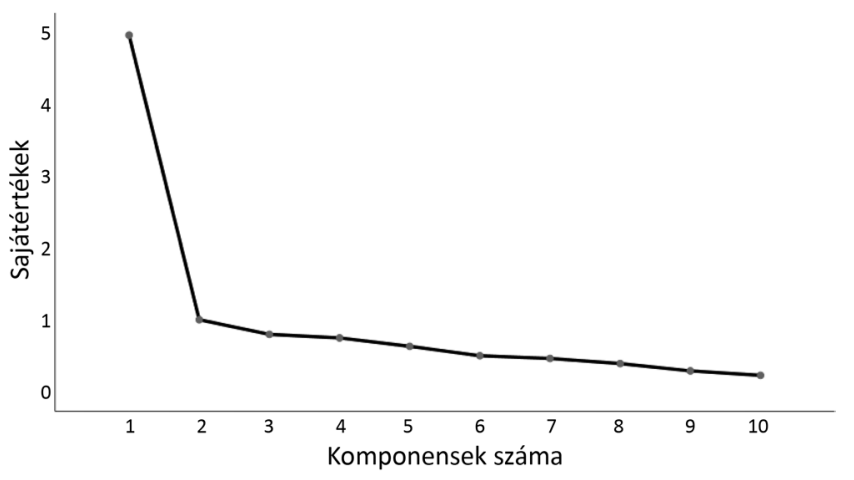

1. ábra | A PSS COVID-19 fókomponens-elemzésének lejtőgörbéje

alapján megállapítható, hogy a főkomponens a variancia 49,68\%-át magyarázta, a második komponens a variancia 10\%-át, vagyis ez utóbbi komponens éppen csak elfogadható a Kaiser-kritérium alapján. Ezt támasztja alá a lejtődiagram is (1. ábra).

A párhuzamos elemzés során csupán a fókomponens (az első komponens) sajátértéke haladta meg a random generált adathalmaz komponenseinek sajátértékét, ami szintén arra utal, hogy a PSS COVID-19 egykomponensû skála. Az egyes itemek faktorsúlyai a fókomponensen 0,83 és 0,51 között változtak (1. táblázat).

\section{Konvergens és divergens validitás, belsö konzisztencia}

A PSS-PAN konvergens validitását támasztja alá, hogy szignifikánsan, pozitívan korrelált az általános észlelt stressz szintjével $(\mathrm{r}=0,46 ; \mathrm{n}=1164 ; \mathrm{p}<0,001)$, a depressziós tünetegyüttessel $(\mathrm{r}=0,4 \mathrm{l} ; \mathrm{n}=1164 ; \mathrm{p}<0,001)$, valamint divergens validitását, hogy negatívan korrelált az élettel való elégedettség mértékével $(r=-0,29$; $\mathrm{n}=1164 ; \mathrm{p}<0,001)$. A PSS-PAN Cronbach-alfája 0,89

1. táblázat $\mid$ A PSS-PAN tételeinek faktorsúlyai, átlagai, szórásai, korrigált item-totál korrelációi, valamint a Cronbach-alfa-értékek az adott tétel nélkül

\begin{tabular}{llllll}
\hline Tételek & $\begin{array}{l}\text { Faktor- } \\
\text { súlyok }\end{array}$ & Átlag & Szórás & $\begin{array}{l}\text { Korrigált } \\
\text { item-totál } \\
\text { korreláció }\end{array}$ & $\begin{array}{l}\text { Cronbach-alfa } \\
\text { a tétel nélkül }\end{array}$ \\
\hline PSS-PAN1 & 0,829 & 1,84 & 1,030 & 0,683 & 0,865 \\
PSS-PAN2 & 0,824 & 1,45 & 1,104 & 0,754 & 0,859 \\
PSS-PAN3 & 0,767 & 1,74 & 1,115 & 0,750 & 0,859 \\
PSS-PAN4 & 0,765 & 1,06 & 0,866 & 0,549 & 0,875 \\
PSS-PAN5 & 0,765 & 2,27 & 1,048 & 0,478 & 0,880 \\
PSS-PAN6 & 0,705 & 1,36 & 1,089 & 0,427 & 0,885 \\
PSS-PAN7 & 0,641 & 1,09 & 0,810 & 0,617 & 0,871 \\
PSS-PAN8 & 0,597 & 1,61 & 1,027 & 0,691 & 0,865 \\
PSS-PAN9 & 0,563 & 2,18 & 1,058 & 0,508 & 0,878 \\
PSS-PAN10 & 0,512 & 1,20 & 1,056 & 0,686 & 0,865 \\
\hline
\end{tabular}

PSS-PAN = az Észlelt Stressz Kérdőív járványspecifikus verziója volt, amely kiváló belső konzisztenciát jelent. A Cronbach-alfa-érték az egyes itemek kivonása során is magas maradt, vagyis magas reliabilitást jelzett. Továbbá az erős item-totál korrelációk is az eszköz megbízhatóságát támasztják alá (1. táblázat).

\section{A PSS-PAN szociodemográfiai változókkal való összefüggésének vizsgálata}

A kétmintás t-próba alapján a nők PSS-PAN-pontszámátlaga szignifikánsan magasabb volt, mint a férfiaké $(\mathrm{t}=$ $-7,135 ; \mathrm{p}<0,001)$. Fontos megjegyezni azonban, hogy a Cohen-féle eljárással a hatásnagyság alacsonynak bizonyult $(\mathrm{d}=0,06)$, jóval az általánosan alacsony küszöbértéknek elfogadott 0,2-es érték alá esik. Vagyis a férfiak és a nők átlaga közötti különbség statisztikailag szignifikáns, de elenyésző nagyságú ezen a mintán. A szocioökonómiai státuszra lefuttatott egyszempontos varianciaanalízis hasonló eredményt hozott: szignifikáns volt ugyan, de a hatásméret az alacsony tartományban ma$\operatorname{radt}\left(\mathrm{F}_{(4 ; 1159)}=3,461 ; \mathrm{p}=0,01 ; \eta^{2}=0,01\right)$. A Bonferroni-féle post hoc teszt szerint a magukat alsó középosztályba sorolók PSS-PAN-pontszámátlaga szignifikánsan magasabb volt a középosztályba tartozókéhoz képest $(\mathrm{p}=0,04)$, a többi csoport viszont nem különbözött egymástól szignifikánsan. A PSS-PAN pontszámának átlagai nem különböztek szignifikánsan a legmagasabb iskolai végzettség egyes kategóriái mentén $\left(\mathrm{F}_{(6 ; 1157)}=\right.$ 2,$\left.035 ; \mathrm{p}=0,06 ; \eta^{2}=0,01\right)$. A PSS-PAN-pontszám nem korrelált szignifikánsan az életkorral sem $(\mathrm{r}=-0,04 ; \mathrm{n}=$ $1164 ; \mathrm{p}=0,13)(2$. táblázat).

\section{Megbeszélés}

Tudomásunk szerint elsóként fejlesztettünk ki egy olyan magyar nyelvú skálát, amely a COVID-19-járvány pszichés hatását hivatott felmérni. Célunk az volt, hogy a PSS minimális módosításával olyan eszközhöz jussunk, amellyel kifejezetten a járvánnyal kapcsolatban megélt stressz mérhető.

Igazoltuk, hogy a teszt validitása összességében jó, a legmagasabb iskolai végzettség tekintetében nem különbözött szignifikánsan az átlagpontszám, az életkorral pedig nem korrelált. A férfiak és a nők átlagpontszáma közötti különbség szignifikáns, de a hatásnagyság-mutató alapján elenyésző mértékü, így valószínűsíthető, hogy a járvánnyal kapcsolatos stressz nagyon hasonlóan hat mindkét nemre. Ezenkívül az átlagpontszám szignifikánsan különbözött az egyes szocioökonómiai kategóriák között, viszont a hatásnagyság ezúttal is nagyon csekély volt. A skála közepes erősséggel korrelált az általános észlelt stresszt és a depressziót mérő skálák pontszámaival, valamint gyengén korrelált az élettel való elégedettség pontszámával, ami támogatja a COVID-19 PSS validitását; ugyanakkor az, hogy az összefüggések sehol sem utaltak erős korrelációra, azt is alátámasztja, hogy a skála 
2. táblázat $\quad$ A PSS-PAN pontszámának átlaga és szórása nemenkénti, korcsoportos, legmagasabb iskolai végzettség szerinti, valamint szocioökonómiai státusz szerinti bontásban.

\begin{tabular}{|c|c|c|c|c|c|c|c|c|}
\hline \multirow[t]{3}{*}{ Nem } & & & $\begin{array}{l}\text { Férfi } \\
\mathrm{n}=184\end{array}$ & $\begin{array}{l}\text { Nö } \\
\mathrm{n}=980\end{array}$ & & & & \multirow[t]{3}{*}{$\begin{array}{l}\mathrm{t}=-7,09 \\
\mathrm{p}=0,00\end{array}$} \\
\hline & \multicolumn{7}{|c|}{ Nemenkénti PSS-PAN-pontszámátlag (szórás) } & \\
\hline & & & $\begin{array}{l}12,45 \\
(6,93)\end{array}$ & $\begin{array}{l}16,43 \\
(7,00)\end{array}$ & & & & \\
\hline \multirow[t]{3}{*}{$\begin{array}{l}\text { Legmagasabb } \\
\text { iskolai végzettség }\end{array}$} & $\begin{array}{l}8 \text { általános } \\
\mathrm{n}=10\end{array}$ & $\begin{array}{l}\text { Szakmunkás } \\
\mathrm{n}=55\end{array}$ & $\begin{array}{l}\text { Érettségi } \\
\mathrm{n}=213\end{array}$ & $\begin{array}{l}\text { Technikum } \\
\mathrm{n}=74\end{array}$ & $\begin{array}{l}\text { Főiskola } \\
\mathrm{n}=346\end{array}$ & $\begin{array}{l}\text { Egyetem } \\
\mathrm{n}=433\end{array}$ & $\begin{array}{l}\mathrm{PhD} \\
\mathrm{n}=33\end{array}$ & \multirow[t]{3}{*}{$\begin{array}{l}\mathrm{F}=2,03 \\
\mathrm{p}=0,06\end{array}$} \\
\hline & \multicolumn{7}{|c|}{ Iskolai végzettség szerinti PSS-PAN-pontszámátlag (szórás) } & \\
\hline & $\begin{array}{l}17,40 \\
(7,26)\end{array}$ & $\begin{array}{l}15,65 \\
(6,16)\end{array}$ & $\begin{array}{l}14,90 \\
(7,76)\end{array}$ & $\begin{array}{l}15,27 \\
(6,32)\end{array}$ & $\begin{array}{l}15,41 \\
(6,99)\end{array}$ & $\begin{array}{l}16,47 \\
(7,06)\end{array}$ & $\begin{array}{l}17,94 \\
(7,97)\end{array}$ & \\
\hline \multirow[t]{3}{*}{ SES } & $\begin{array}{l}\text { Alsó osztály } \\
\mathrm{n}=15\end{array}$ & $\begin{array}{l}\text { Alsó } \\
\text { középosztály } \\
\mathrm{n}=252\end{array}$ & $\begin{array}{l}\text { Középosztály } \\
\mathrm{n}=718\end{array}$ & $\begin{array}{l}\text { Felső } \\
\text { középosztály } \\
\mathrm{n}=171\end{array}$ & $\begin{array}{l}\text { Felső osztály } \\
\mathrm{n}=8\end{array}$ & & & \multirow[t]{3}{*}{$\begin{array}{l}\mathrm{F}=3,46 \\
\mathrm{p}=0,01\end{array}$} \\
\hline & \multicolumn{7}{|c|}{ SES szerinti PSS-PAN-pontszámátlag (szórás) } & \\
\hline & $\begin{array}{l}19,60 \\
(6,23)\end{array}$ & $\begin{array}{l}16,92 \\
(7,25)\end{array}$ & $\begin{array}{l}15,43 \\
(6,98)\end{array}$ & $\begin{array}{l}15,51 \\
(7,44)\end{array}$ & $\begin{array}{l}13,25 \\
(7,76)\end{array}$ & & & \\
\hline \multicolumn{7}{|c|}{ PSS-PAN és az életkor korrelációja: } & $\begin{array}{l}\mathrm{r}=0,04 \\
\mathrm{p}=0,13\end{array}$ & \\
\hline
\end{tabular}

PSS-PAN = az Észlelt Stressz Kérdő́iv járványspecifikus verziója; SES = szocioökonomóiai státusz

\section{Melléklet}

Az alábbi kérdések azokra az érzésekre és gondolatokra vonatkoznak, amelyek Önt AZ ELMÚLT HÓNAP SORÁN jellemezték a KORONAVÍRUS-JÁRVÁNY KAPCSÁN. Kérjük, hogy minden egyes kérdésnél írja be, hogy az elmúlt hónap során MILYEN GYAKRAN volt jellemző Önre az adott érzés vagy gondolat. Néhány kérdés hasonlónak tünik ugyan, de valójában különbözőek, ezért kérjük, hogy valamennyit külön kérdésként kezelje. A legjobb, ha minden kérdésre gyorsan válaszol. Tehát ne próbálja megszámolni, hogy hányszor érezte magát egy adott módon, hanem írja be azt a választ, amely a leginkább jellemzőnek tűnik.

\begin{tabular}{|c|c|c|c|c|c|}
\hline & Soha & $\begin{array}{c}\text { Szinte } \\
\text { soha }\end{array}$ & Néha & $\begin{array}{c}\text { Elég } \\
\text { gyakran }\end{array}$ & $\begin{array}{l}\text { Nagyon } \\
\text { gyakran }\end{array}$ \\
\hline $\begin{array}{l}\text { 1. Az elmúlt hónap során milyen gyakran volt feszült valamilyen, } \\
\text { a járvánnyal kapcsolatos váratlan esemény miatt? }\end{array}$ & 0 & 1 & 2 & 3 & 4 \\
\hline $\begin{array}{l}\text { 2. Az elmúlt hónap során milyen gyakran érezte úgy, hogy } \\
\text { a járvány miatt képtelen kézben tartani azokat a dolgokat, amelyek fontosak } \\
\text { az életében? }\end{array}$ & 0 & 1 & 2 & 3 & 4 \\
\hline $\begin{array}{l}\text { 3. Az elmúlt hónap során milyen gyakran érezte magát idegesnek és stresszesnek } \\
\text { a járvány miatt? }\end{array}$ & 0 & 1 & 2 & 3 & 4 \\
\hline $\begin{array}{l}\text { 4. Az elmúlt hónap során milyen gyakran bízott magában, hogy képes megoldani } \\
\text { a járvánnyal kapcsolatos személyes problémáit? }{ }^{a}\end{array}$ & 0 & 1 & 2 & 3 & 4 \\
\hline $\begin{array}{l}\text { 5. Az elmúlt hónap során milyen gyakran érezte úgy, hogy a dolgok az Ön kedve } \\
\text { szerint alakulnak a járványt illetően?a }\end{array}$ & 0 & 1 & 2 & 3 & 4 \\
\hline $\begin{array}{l}\text { 6. Az elmúlt hónap során milyen gyakran érezte úgy, hogy nem tud eleget tenni } \\
\text { annak, hogy kontrollálja a lehetséges fertőzést? }\end{array}$ & 0 & 1 & 2 & 3 & 4 \\
\hline $\begin{array}{l}\text { 7. Az elmúlt hónap során milyen gyakran tudta kezelni a járvánnyal kapcsolatos } \\
\text { bosszúságokat az életében?a }\end{array}$ & 0 & 1 & 2 & 3 & 4 \\
\hline $\begin{array}{l}\text { 8. Az elmúlt hónap során milyen gyakran érezte úgy, hogy a járvány alatt a helyzet } \\
\text { magaslatán áll?a }\end{array}$ & 0 & 1 & 2 & 3 & 4 \\
\hline $\begin{array}{l}\text { 9. Az elmúlt hónap során milyen gyakran dühítették fel olyan, a járványhoz kötődő } \\
\text { dolgok, amelyeket nem tudott befolyásolni? }\end{array}$ & 0 & 1 & 2 & 3 & 4 \\
\hline $\begin{array}{l}\text { 10. Az elmúlt hónap során milyen gyakran érezte úgy, hogy a nehézségek a járvány } \\
\text { időszaka alatt úgy felhalmozódtak, hogy már nem tud úrrá lenni rajtuk? }\end{array}$ & 0 & 1 & 2 & 3 & 4 \\
\hline
\end{tabular}

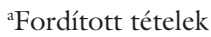


önálló, a többitől eltérő konstruktumot mér. A korrelációs eredmények a bevezetőben megfogalmazott hipotéziseinket is alátámasztják. Végül a skála belső konzisztenciája, reliabilitása is kiválónak minősíthető.

A vizsgálat korlátai között meg kell említeni, hogy csak online adatgyưjjtés formájában valósult meg, ez eleve kiszưrte a populáció egy részét. Továbbá a nők jóval nagyobb arányban vettek részt a kitöltésben, mint a férfiak. Végül viszonylag kevés pszichológiai konstruktummal vizsgáltuk a konvergens, illetve divergens validitást. Mindezen korlátok ellenére a skála alapvető pszichometriai mutatói jók, s így a mérôeszköz további használata javasolható azokban a kutatásokban, melyekben a COVID-19- vagy más járványok mentális hatásait, illetve azok más változókkal való kapcsolatait igyekeznek a kutatók jobban megérteni (Melléklet).

Anyagi támogatás: A közlemény megírása, a kutatómunka, illetve a kutatási folyamat bármilyen más része nem részesült anyagi támogatásban.

Szerzôi munkamegosztás: H. Cs.: A téma felvetése, mintavétel, a tesztbattéria összeállítása, a szöveg megírása, a statisztikai próbák kivitelezése, értelmezése. F. Á.: A végleges szöveg átnézése, véleményezése. K. T. B.: A tesztbattéria áttekintése, statisztikai tanácsadás, a végleges szöveg átnézése és korrektúrája. A cikk végleges változatát valamennyi szerző elolvasta és jóváhagyta.

Érdekeltségek: A szerzőknek nincsenek érdekeltségeik.

\section{Irodalom}

[1] World Health Organization. Coronavirus disease (COVID-19). Questions \& answers. WHO, Geneva, October 2020. Available from: https://www.who.int/emergencies/diseases/novel-coronavirus-2019/question-and-answers-hub/q-a-detail/coronavirus-disease-covid-19 [accessed: January 27, 2021].

[2] Johns Hopkins Coronavirus Resource Center. Covid-19 Dashboard by the Center for Systems Science and Engineering at Johns Hopkins University. Baltimore, MD, 2021. Available from: https://coronavirus.jhu.edu/map.html [accessed: January 27,2021$]$.

[3] Salari N, Hosseinian-Far A, Jalali R, et al. Prevalence of stress, anxiety, depression among the general population during the COVID-19 pandemic: a systematic review and meta-analysis. Global Health 2020; 16: 57.

[4] Polinski KJ, Bemis EA, Feser M, et al. Perceived stress and inflammatory arthritis: a prospective investigation in the studies of the etiologies of rheumatoid arthritis cohort. Arthritis Care Res (Hoboken). 2020; 72: 1766-1771.
[5] Martínez de Toda I, Miguélez L, Siboni L, et al. High perceived stress in women is linked to oxidation, inflammation and immunosenescence. Biogerontology 2019; 20: 823-835.

[6] Moon HJ, Seo JG, Park SP. Perceived stress in patients with migraine: a case-control study. J Headache Pain 2017; 18: 73.

[7] Edman JS, Greeson JM, Roberts RS, et al. Perceived stress in patients with common gastrointestinal disorders: associations with quality of life, symptoms and disease management. Explore (NY) 2017; 13: 124-128.

[8] Zandifar A, Badrfam R, Yazdani S. Prevalence and severity of depression, anxiety, stress and perceived stress in hospitalized patients with COVID-19. J Diabetes Metab Disord. 2020; 19: $1-8$.

[9] Xu C, Xu Y, Xu S, et al. Cognitive reappraisal and the association between perceived stress and anxiety symptoms in COVID-19 isolated people. Front Psychiatry 2020; 11: 858.

[10] Cortez PA, Joseph SJ, Das N, et al. Tools to measure the psychological impact of the COVID-19 pandemic: what do we have in the platter? Asian J Psychiatr. 2020; 53: 102371.

[11] Pedrozo-Pupo JC, Pedrozo-Cortés, MJ, Campo-Arias A. Perceived stress associated with COVID-19 epidemic in Colombia: an online survey. [Estrés percibido relacionado con la epidemia de COVID-19 en Colombia: una encuesta en línea.] Cad Saude Publica 2020; 36: e00090520. Doi: 10.1590/0102$311 \times 00090520$.

[12] Cohen S, Kamarck T, Mermelstein R. A global measure of perceived stress. J Health Soc Behav. 1983; 24: 385-396.

[13] Stauder A, Konkolÿ Thege B. Characteristics of the Hungarian version of the Perceived Stress Scale (PSS). [Észlelt Stressz Kérdőív (PSS) magyar verziójának jellemzői.] Mentalhig Psychosomat. 2006; 7: 203-216. [Hungarian]

[14] Rózsa S, Szádóczky E, Füredi J. Psychometric properties of the Hungarian version of the shortened Beck Depression Inventory. [A Beck depresszió kérdốiv rövidített változatának jellemzői hazai mintán.] Psychiatr Hung. 2001; 16: 384-402. [Hungarian]

[15] Beck AT, Ward, CH, Mendelson M, et al. An inventory for measuring depression. Arch Gen Psychiatry 1961; 4: 561-571.

[16] Diener E, Emmons RA, Larsen RJ, et al. The Satisfaction with Life Scale. J Pers Assess. 1985; 49: 71-75.

[17] Martos T, Sallay V, Désfalvi J, et al. Psychometric characteristics of the Hungarian version of the Satisfaction with Life Scale (SWLS-H). [Az Élettel való Elégedettség Skála magyar változatának (SWLS-H) pszichometriai jellemzői.] Mentalhig Pszichoszomat. 2014; 15: 289-303. [Hungarian]

[18] Horn JL. A rationale and test for the number of factors in factor analysis. Psychometrika 1965; 30: 179-185.

[19] Patil VH, Singh SN, Mishra S, et al. Parallel analysis engine to aid determining number of factors to retain using R. 2017. Available from: https://analytics.gonzaga.edu/parallelengine/ [accessed: January 28, 2021].

(Hamvai Csaba dr., Szeged, Sárkány u. 3., 6725 e-mail: hamvai.csaba@gmail.com)

A cikk a Creative Commons Attribution 4.0 International License (https://creativecommons.org/licenses/by/4.0/) feltételei szerint publikált Open Access közlemény, melynek szellemében a cikk bármilyen médiumban szabadon felhasználható, megosztható és újraközölhetö, feltéve, hogy az eredeti szerző és a közlés helye, illetve a CC License linkje és az esetlegesen végrehajtott módositások feltüntetésre kerülnek. (SID_1) 